\title{
Sport for peace in Northern Ireland? Civil society, change and constraint after the $\mathbf{1 9 9 8}$ Good Friday Agreement
}

The British Journal of Politics and International Relations $1-16$

(C) The Author(s) 2016

Reprints and permissions: sagepub.co.uk/journalsPermissions.nav DOI: I0.I I77/|369|48| I6656987 bpi.sagepub.com @SAGE

\author{
David Mitchell \\ Trinity College Dublin, UK
}

\section{Ian Somerville}

University of Leicester, UK

\section{Owen Hargie}

Ulster University, UK

\begin{abstract}
Using the case of Northern Ireland, this article examines how post-conflict transition impacts sports organisations which have traditionally underpinned societal division and what factors facilitate or restrain such organisations from fulfilling peacebuilding functions. The article identifies three peacebuilding functions of sport: in-group socialisation, promoting social cohesion and symbolically representing new identities. Then, after outlining the sporting and political context in Northern Ireland, the article explores changes within the sporting environment stemming from the peace process as well as persistent socio-political barriers to sport's capacity to encourage reconciliation and integration, especially symbolic contestation and territorial segregation. The analysis draws on a public attitudes survey $(n=1210)$ conducted by the authors as part of a major government-funded study. The findings demonstrate the potential of the three peacebuilding functions of sport, yet also, crucially, the constraints imposed by the distinct and divided political context. Avenues for further and comparative research are identified.
\end{abstract}

\section{Keywords}

civil society, ethnic conflict, Northern Ireland, peacebuilding, peace process, sport

\section{Introduction}

What impact does peace and political transition have on civil society groups, specifically sporting organisations, which have traditionally underpinned ethno-political division? Despite the widespread contemporary interest in the links between sport, peace and

\section{Corresponding author:}

David Mitchell, Trinity College Dublin, 683 Antrim Road, Belfast BTI5 4EG, UK.

Email: damitche@tcd.ie 
conflict, this question lacks explicit treatment in the literature. The burgeoning field of 'sport for development and peace' (SDP) (Darnell, 2012; Kidd, 2008) is preoccupied with sport (usually soccer) as an intervention in favour of peacebuilding, not as an existing aspect of civil society, enmeshed in the conflict, although there are some exceptions (e.g. Wood (2013) on football in Bosnia).

A valuable case study in this regard is that of Northern Ireland. While it is well known that sports have been implicated in the region's bitter constitutional politics (Sugden and Bairner, 1993) and that a relatively successful transition away from violence and political exclusion has taken place (recent accounts include Cochrane, 2013; Mitchell, 2015), little attention has been paid to the interrelationship of the peace process and the sporting world. What can we learn about how sports in divided societies, even those sports which are traditionally single-identity, can respond supportively to peacemaking? What contextual factors facilitate or constrain sports bodies from fulfilling a peacebuilding role? How can sport assist the reshaping of group identities which have been embittered and polarised by inter-communal violence?

The article begins by examining the relationship between sport, civil conflict and peace, identifying three peacebuilding functions of sport: in-group socialisation, promoting social cohesion and symbolically representing new identities. The article then explores the divided nature of sport in Northern Ireland and the content and implications of the 1998 'Good Friday' peace agreement. Then, changes within sport stemming from the peace process, as well as persistent barriers to sport's capacity to encourage reconciliation and integration, are examined. The analysis draws on a survey $(n=1210)$ conducted by the authors as part of a major government-funded study on social exclusion and sport (Hargie, Somerville and Mitchell, 2015). It assesses the findings in the light of the three potential peacebuilding functions of sport, noting considerable and innovative contributions from sports yet, crucially, the influence of the distinct and divided political context which constrains sport from exercising these functions fully. Avenues for further and comparative research are identified.

At the outset, definitions of key terms are in order. Northern Ireland is considered a 'deeply divided society', that is, one in which 'conflict exists along a well-entrenched fault line that is recurrent and endemic and that contains the potential for violence between the segments' (Guelke, 2012: 30). Organised sport is treated here as a dimension of civil society, defined as a 'sphere of voluntary action that is distinct from the state, political, private and economic spheres' whose organisations are 'oriented to specific interests' (Spurk, 2010: 8-9). Peacebuilding, in keeping with the classic formulations of Galtung, Boutros-Ghali, Lederach and others, is taken as the broad and long-term project of both structural and interpersonal change intended to avoid a relapse into violent conflict.

\section{Sport, societal division and peace}

The capacity of sport to underpin group divisions exemplifies the fact that, as writers on social capital and civil society make clear, voluntary associational life is not inherently positive but is liable to acting as an incubator of separation and egotism (Paffenholz, 2010, 2014; Paris, 2004; Varshney, 2001). This propensity towards exclusivity is what Putnam (2000) terms the 'dark side' of social capital or what Chambers and Kopstein (2001) refer to as 'bad civil society'. Belloni (2008), meanwhile, notes that in ethnically divided societies, as well as unifying, multi-ethnic, civil society groups (such as human rights groups, trade unions, ecumenical movements) and groups which explicitly foster 
violence and division (for instance paramilitaries), there is a third type: groups which, although eschewing violence, are culturally homogenous and are thus de facto perpetuators of difference and separation.

Participating in in-group activities is not inherently intolerant; as Mac Ginty (2011: 186) emphasises, there are good reasons-convenience, physical security, shared culture - why people perceive the in-group as the natural setting for cultural participation. Yet, civil society groups built on ascriptive criteria such as race, religion or ethnicity are likely to be based on exclusion and conflict with others, since a 'worldview that regards identity as closed, fixed and inherently conflictual underpins a politics of belonging' (Belloni, 2008: 191).

Given the widespread mismatch between identity groups and state borders in the contemporary world, numerous cases of sport exhibiting and expressing political cleavages exist (see McClancy, 1996; Sugden and Bairner, 2000). But a remarkable example is Lebanon, where soccer and basketball teams are part and parcel of the sectarianism and clientelism endemic in Lebanese society and are openly aligned with political/ethnic blocs (Reiche, 2011). Indeed, sport's role as a vehicle for group identity makes it likely that it may not merely mirror social division, but actually exacerbate it, providing a platform for the expression of hostility, group chauvinism and violence, as football did, for example, in the lead-up to the violent disintegration of Yugoslavia (Wood, 2013).

However, contemporary interest among policy-makers, researchers and peace practitioners increasingly gravitates towards sport's potential to transcend division in divided societies. This potential may be theorised variously (see, for example, Cárdenas, 2012; Giulianotti, 2011) but, retaining the present focus on sport as civil society, an instructive way to understand sport's capacity in this regard is via the following threefold framework: sport may promote in-group socialisation, social cohesion and symbolic representation of new identities. The first two of these capacities are drawn from Paffenholz and Spurk's (2010: 67) typology of seven peacebuilding functions of civil society, the other five (protection, monitoring, advocacy, intermediation and facilitation, and service delivery) being less relevant to sports organisations.

In-group socialisation, according to Paffenholz and Spurk, can take two forms. First, it can entail creating a culture of peace through promoting democratic attitudes, capacity building and conflict resolution skills. While some contend that sport is value-neural and holds no intrinsic meaning apart from that which participants give it (Kidd, 2008; Sugden, 2010), Parry (2012: 785) argues that, on the contrary, rule-governed competitive sport is a 'lived experiment' in liberal values, promulgating ideas of social contract, equality before the law, justice, toleration and mutual respect. In any case, sport has an obvious relevance to the second type of in-group socialisation: building or consolidating group confidence and identity, especially within marginalised groups in asymmetric conflicts. However, Paffenholz and Spurk point out the danger that such identity strengthening may encourage behaviour, attitudes and a level of solidarity which are perceived as threatening by outsiders.

Social cohesion goes beyond creating in-group bonds towards forging Putnam's (2000: 22) 'bridging capital' with other groups (Paffenholz and Spurk, 2010: 71-72). This may be promoted by sport in situations where sports and sporting organisations cross social divides, and it is the explicit purpose of sports-based reconciliation interventions such as Peace Players International (Tuohey and Cognato, 2011), Football for Peace (Sugden, 2010) and Open Fun Football Schools (Dorokhina et al., 2011; Gasser and Levinson, 2004). These projects use sport's popularity and accessibility to bring 
people of differing cultural and political identities together, especially young people, with the aim of undermining the group myths and stereotypes which survive through the absence of meaningful contact with the 'other' (Giulianotti, 2012). They implicitly or explicitly follow broad peacebuilding principles such as Allport's (1954) Contact Hypothesis or Lederach's (1997: 26) emphasis on encounter as 'humans-in-relationship' in ending inter-group antagonisms.

To these two peacebuilding functions of sport we add a third: the symbolic representation of co-operation and new identities. If sport can express antagonistic and exclusive identities, it can equally symbolise inclusive and open self-understandings, providing estranged groups a shared focus of allegiance and embedding a political transformation in the popular consciousness. In South Africa, sport provided the platform for totemic representations of the political change taking place, such as Mandela's donning of the Springbok rugby jersey associated with White South Africa, and Black and White athletes travelling to the Barcelona Olympics in 1992 in a plane decorated with the new national flag. Sport also underwent structural change in order to become more representative of South Africa's new democracy (Höglund and Sundberg, 2008; Keim, 2003). Another notable case is that of North and South Korea, where 'trans-national, pan-Korean, identity ... has been reinvigorated by the often emotional celebration of a common cultural heritage and national unity through the various sporting encounters between the two nations' (Merkel, 2008: 308). Nevertheless, the symbolic function of sport can be fleeting and is difficult to quantify; certainly, in the cases mentioned, its achievements should not be exaggerated. The potential impact of unifying symbols, gestures and rituals is acknowledged in the comparative study of peace processes, yet so too is the uncertainty surrounding their long-term effects (Darby and Mac Ginty, 2000: 242).

\section{Sport, conflict and the peace process in Northern Ireland}

Northern Ireland is a deeply divided society (Guelke, 2012: 9) comprising two main political communities: unionists who are pro-British and mainly Protestant, and nationalists who are pro-Irish and mainly Catholic. The origins of the conflict are often attributed to the settlement of Ireland by Britain in the 16th and 17th centuries (see McGarry and O'Leary, 1993; Ruane and Todd, 1996). The opposing political aspirations of the two ethno-political blocs led Britain to partition Ireland in 1920, with 6 counties in the north remaining within the United Kingdom (becoming Northern Ireland) and the remaining 26 counties becoming autonomous. For 50 years, Protestant unionists monopolised power in Northern Ireland in part due to their fear of being subsumed into a Catholic-dominated Southern state. However, grievances of the Catholic minority in the north eventually led in the late 1960s to civil rights demonstrations, civil unrest and the armed campaign of the Irish Republican Army (IRA) aimed at removing British rule from Ireland. Thirty years of violence, the so-called 'Troubles', followed in which over 3500 people were killed.

An early examination of the role of sport in this history of antagonism (Sugden and Bairner, 1993) emphasised how sport tended to mirror rather than challenge the wider conflict, and was pessimistic about the integrative potential of the main sports. Gaelic games, which are played almost exclusively by Catholics in Northern Ireland and taught in Catholic schools, are governed by the Gaelic Athletic Association (GAA), an organisation that was set up in 1884 with an explicitly Irish nationalist purpose of resisting the cultural/sporting Anglicisation of Ireland and promoting political nationalism. The GAA has been overtly anti-unionist and, notably, until 2001, prohibited the participation of 
members of the Northern Ireland state security forces, including thousands of (overwhelmingly Protestant) members of the police force. Hence, it was 'unimaginable' that Protestants could ever support Gaelic games in large numbers (Sugden and Bairner, 1993: 130). Rugby, along with other British-associated sports such as hockey and cricket, was predominantly Protestant and middle class, meaning that although it did enjoy some cross-community support and participation, it was incapable of acting as a unifying force among the working classes who were most directly affected by, and involved in, the political violence. And soccer's popularity in both communities allowed the sport during the period of the Troubles to become a platform for antagonism, affording pro-state Protestants opportunities for displays of 'hegemonic masculinity' and sectarianism (Bairner, 1999: 285) and playing a 'counter hegemonic' role for Catholics wishing to express an Irish identity and alienation from the Northern Irish state (Hassan, 2002: 80). Separate sports curricula in effectively single-identity schools were central to the perpetuation of division in sport, despite some use of sport as part of the government's community-relations education programme 'Education for Mutual Understanding' introduced in the early 1990s (Sugden and Bairner, 1993: 98).

These pessimistic assertions, echoed in subsequent analyses of Northern Ireland sport (see Cronin, 2001), bear out the observation that rather than solely and benignly representing a neutral or moderating constituency, civil society in Northern Ireland has itself been divided and supportive of sectarian politics (Brewer et al., 2011). Sport, along with religion, education, housing and, of course, politics, has been part of the sectarian 'system' which conditions the experiences and life choices of individuals (Liechty and Clegg, 2001: 9). While cross-community civil society peacebuilding movements have made an important contribution to changed political circumstances (see, for example, Byrne, 2001), much sport has represented Belloni's (2008) third type of civil society-helping maintain patterns of separation, even if not explicitly encouraging conflict. The key contemporary questions, therefore, are whether the recent political developments that have taken place were intended to make, were capable of making or have actually made any difference to the single-identity stasis and divisive nature of sport in Northern Ireland.

The consociational power-sharing deal that was reached on Good Friday, 1998, recognised the validity of unionist and nationalist identities, cultures and political aspirations and, in the main, encouraged reciprocal respect and tolerance between the two blocsarguably seeking to manage their competition rather than encourage their demise. This absence of ambition to overcome these identity categories in the Agreement was criticised in some quarters, and indeed, evidence of power-sharing's reconciliatory potential in contexts such as Bosnia, Lebanon and Iraq is notably dubious (Taylor, 2009; Wilson, 2010). Yet, the proponents of consociational power-sharing prescriptions for internal conflicts insist that such arrangements are a necessary response to political realities and that they do have the capacity, by allowing a prolonged period of political stability and crossethnic co-operation, to create a shared identity and allegiance (McGarry and O'Leary, 2009). In addition to its recognition of group identities, the Agreement contained powerful human rights protections and a range of measures designed to decrease the salience of ethnicity. These included police reform, demilitarisation, the disarmament of paramilitary groups and recognising victims (Higson, 2008). Furthermore, although the Agreement affirmed the two main traditions, it also enshrined the right to reject the traditional binary, confirming people's right to hold both British and Irish citizenship simultaneously.

The likely impact of the Agreement on sport, culture and civil society, then, was uncertain. On one hand, single-identity sport would in theory erode organically over time as a 
result of the improved security situation, political stability and a new political culture of tolerance and respect. On the other hand, the vulnerabilities caused by mandatory powersharing, the uncertainty surrounding the constitutional future (the Agreement permitted Northern Ireland to leave the United Kingdom should a majority, at some point, favour this) and the absence of any energetic plan to encourage inter-communal mixing made it likely that cultural assertion might take the place of the military struggle, and social division would persist.

As we explore in the next section, both of these tendencies have been in evidence since 1998. First, we examine developments within sport as well as findings from our survey that suggest sport may be following a trajectory away from its role as a marker of societal division and towards greater inclusivity. Second, we discuss persistent barriers to greater inclusivity and integration, particularly in relation to symbolic and territorial contestation, as well as certain public attitudes which suggest continuity with traditional divisions.

The survey $(n=1210)$, designed by the authors, probed attitudes on a range of issues pertaining to sport, sectarianism and inclusion/exclusion and was included as part of the annual Northern Ireland Life and Times Survey (ARK, 2014). The survey items were developed from the findings of a comprehensive literature review and semi-structured, face-to-face interviews with members of the public [!] and representatives of sports bodies concerning perceived successes and failures in creating more inclusive sports cultures in Northern Ireland. The survey respondents comprised a systematic random sample drawn from the Postcode Address File database of addresses. In terms of religious community background, $40 \%$ of respondents identified as Protestant, $41 \%$ as Catholic, $17 \%$ as no religion and $1 \%$ as 'other'. This compares with proportions recorded in the 2011 Northern Ireland census when 48\% identified as being from a Protestant community background, $45 \%$ as being from a Catholic community background, $6 \%$ as no religion and $1 \%$ as refused/missing. ${ }^{1}$ The survey was conducted through face-to-face interviews with persons over 18 years of age in their homes.

The researchers' choice of a public attitudes survey is a response to the marked qualitative emphasis of the overwhelming majority of research on sport in Northern Ireland, and indeed the paucity of primary research of any kind. As is the inherent limitation of the survey approach, the results reported here are a snapshot; as the first survey of its kind, the findings provide benchmarks that will allow the all-important longitudinal study of public attitudes to sport, inclusion and political change. Furthermore, since meaning and causality are not always apparent from the descriptive statistics, the findings are contextualised with analysis of media sources and a variety of pertinent available research. Although gender, age and class were also investigated and analysed in the research project, the focus in this article is on the impact of religious community background, specifically on attitudes to sport and peacebuilding and to the three main stadium sports and governing bodies, soccer, Gaelic games and rugby union, the sports which have been most associated with national identity politics.

\section{Sport after the 1998 Agreement: signs of a new inclusivity}

The peace process catalysed several significant 'top-down' initiatives and reforms in the sporting world. Perhaps the most direct result of political change was the GAA's repeal of its rule excluding the security forces from membership. This occurred in November 2001 in response to the enactment of measures to make the police force more accountable, 
transparent and representative of the Catholic community (Hassan, 2005). Since then, a Police Service of Northern Ireland (PSNI) Gaelic football team has been formed. In April 2011, the GAA's very public show of support at the funeral of a police officer, Ronan Kerr, who was murdered by republicans opposed to the peace process, and who was a GAA member, demonstrated the extent to which the organisation had embraced and endorsed the new political dispensation (Hassan and Telford, 2014). The GAA has also made efforts to develop links with the unionist community through forming crosscommunity teams and, in a hugely symbolic gesture, welcomed Queen Elizabeth II to the home of the GAA, Croke Park in Dublin, in June 2011. These developments, unthinkable in the past, should be understood in the light not solely of the GAA's traditional exclusivism but also the problems the organisation experienced due to the actions of loyalist paramilitaries and state security forces during the Troubles (Hassan and O'Kane, 2012).

Soccer has also undergone a process of self-examination in tune with the political times. Windsor Park, the home of Northern Ireland international soccer, has since the onset of the Troubles been viewed by some as a bastion of working-class unionist identity (Bairner, 1999), but a spike in sectarian trouble in the early 2000s led to a high-profile community-relations campaign, 'Football for All', funded by the European Union (EU) peace programme, aimed at eradicating sectarianism from the game, particularly at home internationals. Independent evaluations found the campaign to be extremely effective (Wilson, 2005, 2011). Although the least politically tainted of the three sports, rugby too has evolved, in that the professionalisation of the game and increased television coverage have broadened the sport beyond the traditional social networks embedded in privileged, mainly Protestant, schools. The Ireland international team has always included players from North and South of the border, and in an effort to be inclusive, since 1995, a specially commissioned neutral anthem, 'Ireland's Call', neither British nor Irish, has been used at matches, although the anthem of the Republic of Ireland is still played at home games (Clerkin, 2015). Since 2012, the three largest sports have been working in partnership through the Northern Ireland government-funded programme, 'Sport in the Community', with the aim of shared learning towards improving volunteering, club development and cross-community relationships (Belfast Telegraph, 2012).

Meanwhile, sport has acted as the vehicle for a number of significant 'bottom-up' peacebuilding projects. Peace Players International has been active in Northern Ireland since 2002, using basketball, a 'neutral' sport in the region and many other conflict zones, to develop contact between young people from differing political backgrounds (see Tuohey and Cognato, 2011). The organisation has implemented, in conjunction with the three main sports, the 'Game of Three Halves', a programme which exposes young people from different backgrounds to all three sports in combination with communityrelations education. Furthermore, in symbolic acts of outreach across the sectarian divide, leaders from the main unionist and nationalist parties have taken the unprecedented steps of attending sports associated with the other community. However, Sinn Féin Minister Carál Ní Chuilín took her seat at the Northern Ireland match which she attended after the British national anthem had been played, and Democratic Unionist Party (DUP) Minister Edwin Poots took his seat at the GAA match he attended after the Irish anthem had been played (British Broadcasting Corporation, 2011).

In support of these developments, our survey found that an overwhelming majority of respondents (84\%) agreed with the proposition that 'sports in Northern Ireland are more open and inclusive than ten years ago'. Moreover, a similar proportion (86\%) agreed or 
Table I. 'Thinking about some of the main organisers of team sports in $\mathrm{NI}$, do you think that the following organisations are taking active steps to welcome all traditions in NI?'.

\begin{tabular}{llllllc}
\hline & & $\begin{array}{l}\text { Yes } \\
\text { definitely (\%) }\end{array}$ & $\begin{array}{l}\text { Yes } \\
\text { probably (\%) }\end{array}$ & $\begin{array}{l}\text { Don't } \\
\text { know (\%) }\end{array}$ & $\begin{array}{l}\text { No probably } \\
\text { not (\%) }\end{array}$ & $\begin{array}{l}\text { No definitely } \\
\text { not (\%) }\end{array}$ \\
\hline The Gaelic & Catholics & 20.0 & 40.2 & 15.7 & 20.4 & 3.7 \\
Athletic & Protestants & 5.5 & 24.3 & 25.9 & 31.4 & 12.9 \\
Association & No religion & 6.2 & 25.6 & 37.0 & 24.6 & 6.6 \\
& All & 11.6 & 31.0 & 23.7 & 25.7 & 8.0 \\
The Irish & Catholics & 14.6 & 40.6 & 21.6 & 19.2 & 3.9 \\
Football & Protestants & 9.0 & 39.0 & 25.7 & 21.4 & 4.9 \\
Association & No religion & 6.2 & 35.5 & 34.1 & 21.8 & 2.4 \\
& All & 10.8 & 39 & 25.5 & 20.6 & 4.0 \\
Ulster & Catholics & 21.0 & 41.6 & 23.3 & 12.0 & 2.1 \\
Rugby & Protestants & 17.1 & 44.7 & 24.1 & 12.7 & 1.4 \\
& No religion & 21.3 & 32.7 & 33.6 & 11.8 & 0.5 \\
& All & 19.5 & 41.3 & 25.5 & 12.2 & 1.5 \\
\hline
\end{tabular}

Source: ARK (2014).

strongly agreed that 'sport is a good way to break down barriers between Protestants and Catholics'. Such figures should give added impetus to the focus on sport as a peacebuilding tool contained in the power-sharing Executive's current community-relations strategy, Together: Building a United Community (Office of the First Minister and Deputy First Minister, 2013). More specifically, we sought to gauge the public perception of the three main sporting bodies' inclusivity efforts by asking 'Thinking about some of the main organisers of team sports in NI, do you think that the following organisations are taking active steps to welcome all traditions in NI?'

As shown in Table 1, regarding the GAA, $42.6 \%$ of the sample responded 'yes definitely' or 'yes probably' and $33.7 \%$ responded 'no probably not' or 'no definitely not'. Many more Catholics than Protestants held a positive view of the inclusivity efforts of the GAA: $60.2 \%$ compared to $29.8 \%$. Regarding the Irish Football Association (IFA), governing body of soccer in Northern Ireland, $49.8 \%$ of the sample responded 'yes definitely' or 'yes probably' and $24.6 \%$ responded 'no probably not' or 'no definitely not'; in terms of religious background, $55.2 \%$ of Catholics and $48 \%$ of Protestants were positive. And in relation to Ulster Rugby, $60.8 \%$ of the sample responded 'yes definitely' or 'yes probably' and $13.7 \%$ responded 'no probably not' or 'no definitely not'. This included $62.6 \%$ of Catholics who were positive and $61.8 \%$ of Protestants.

While all the sporting bodies were viewed more positively than negatively, the GAA, notably, has much further to travel in terms of securing cross-community confidence. Unsurprisingly, Catholics held a more positive view of the GAA than Protestants, although it is significant that a large minority of Catholics (24.1\%) believed that the GAA was not doing enough to welcome all traditions. Interestingly, Ulster Rugby has probably taken the fewest 'active steps' to welcome all traditions, but scores well here because it enjoys the positive cross-community regard within which rugby is viewed. It is also striking that Catholics held a more positive view of the IFA than Protestants. This suggests that the efforts of the IFA to eradicate sectarianism from the Northern Ireland international game have been recognised within the Catholic community. 


\section{Sport after the 1998 Agreement: the persistence of communal exclusivity}

Despite the change in the sporting world stimulated by the peace process, there is evidence that patterns of separation persist in sport, patterns which reflect broader and enduring social divisions. At the most basic level, the religious community background of the support bases of the main sports appears to continue to follow traditional lines. For instance, we investigated levels of television viewing of Gaelic games, soccer and rugby. Only $1.3 \%$ of Protestants reported watching 'a lot' of Gaelic games on television, compared with $30.5 \%$ of Catholics. A figure of $22.8 \%$ of Protestants had watched Northern Ireland international soccer 'a lot' compared with a much smaller proportion-9.8\% - of Catholics, while $17.9 \%$ of Catholics and $28 \%$ of Protestants had watched Ulster rugby matches 'a lot'.

These differentials are consistent with research into attendance at live sporting events which shows that in 2011/2012, 20\% of Catholics attended a live GAA match compared to fewer than $1 \%$ of Protestants (Mallon, 2013). Similar numbers of each community-11\% of Protestants and $8 \%$ of Catholics - had attended a live soccer match. A total of $9 \%$ of Protestants and $4 \%$ of Catholics had attended a live rugby match, and these tended to come from the least deprived areas. Hockey and cricket were attended almost exclusively by Protestants. In our survey, a majority of the sample actually appeared to be unconcerned by the principle of separate sports for separate communities. In response to the item 'There is nothing wrong with different sports or teams being for Protestants or Catholics', 57\% of people agreed or strongly agreed, with little difference in the opinions of Protestants and Catholics.

Moreover, the ongoing constitutional question continues to impinge upon sport. As indicated by the pointed absences of the politicians during the playing of the anthems at the matches they attended, the playing of the British national anthem at international soccer matches and the Irish national anthem at some GAA matches continues to create a chill factor for the 'other side'. This is symptomatic of wider cultural tensions; as McCall (2006: 313) states plainly, the mutual uncertainties instituted by the peace have meant that 'culture has become a primary site for the perpetuation of the unionist-nationalist ethnonational conflict'. While Northern Ireland is officially part of the United Kingdom, nationalists have argued that limitations should be placed on the display of British state symbols out of sensitivity to the (Irish) identity and culture of Catholics. This contention has led to a series of post-1998 disputes over the appropriate display of flags and emblems, the most bitter of which was the decision in December 2012 by Belfast City Council to restrict the display of the British flag from City Hall which precipitated months of street protests by unionists (see Nolan et al., 2014).

The present research shows opinion closely divided on the topic of anthems in sport. Thus, as shown in Table 2, 35.4\% of the sample agreed or strongly agreed that 'national anthems should not be part of sport in Northern Ireland', while $42.2 \%$ disagreed or strongly disagreed; $52.8 \%$ of Protestants disagreed compared to $36.6 \%$ of Catholics and $31.8 \%$ of the no religion group. These differences may be expected given how many Protestants have felt their identity and culture to be threatened by the peace process, especially in the wake of the flag dispute. The divisiveness of the issue suggests, first, that change in the use of anthems may need to be negotiated and synchronised between sports and, second, that any change must command the support of the political parties and the 
Table 2. 'National anthems should not be part of sport in Northern Ireland'.

\begin{tabular}{lclllc}
\hline & $\begin{array}{l}\text { Strongly } \\
\text { agree (\%) }\end{array}$ & Agree (\%) & $\begin{array}{l}\text { Neither agree } \\
\text { nor disagree (\%) }\end{array}$ & $\begin{array}{l}\text { Disagree } \\
(\%)\end{array}$ & $\begin{array}{l}\text { Strongly } \\
\text { disagree (\%) }\end{array}$ \\
\hline Catholics & 9.8 & 32.2 & 21.4 & 28.7 & 7.9 \\
Protestants & 7.0 & 20.7 & 20.5 & 35.3 & 16.5 \\
No religion & 11.5 & 27.6 & 29.2 & 25.5 & 6.3 \\
All & 8.9 & 26.5 & 22.4 & 31.0 & 11.2 \\
\hline
\end{tabular}

Source: ARK (2014).

wider public, and take place in the context of greater consensus at the party-political level in relation to cultural expression.

At the same time, greater mixing in social life continues to be hamstrung by the ongoing sectarian division of territory. Paramilitary control persists in working-class areas, as does sectarian rioting, especially in 'interface' zones where Protestant and Catholic areas meet, meaning that territorial awareness continues to be regarded as important for personal security. Territorial division is at its most stark along the so-called 'peace walls', barriers separating Protestant and Catholic housing designed to prevent rioting and attacks. Research on attitudes to peace walls found that $78 \%$ of people across Northern Ireland believe that the territorial segregation of Protestants and Catholics is common even where there are no peace walls (Byrne et al., 2012: 27). Allied to this is the fact that $93.5 \%$ of school children continue to be educated in predominantly Protestant or predominantly Catholic schools and thus remain subject to different sports curricula (Nolan, 2014: 120).

What impact does territorial division have on the inclusivity of the three big sports? Our survey posed a scenario in which respondents were offered free tickets to each of the three main sporting venues. Casement Park, the GAA stadium, is in nationalist West Belfast and was in close proximity to a number of violent incidents during the Troubles. Furthermore, the eponymous Roger Casement was a nationalist hero of the Irish revolutionary era at the start of the 20th century; other GAA grounds have been named after individuals whom unionists regard as Irish republican terrorists. Ulster's provincial rugby ground, Ravenhill, is in a predominantly unionist area of Belfast, although it has never been associated with sectarian trouble. The national soccer stadium, Windsor Park, is located in a traditionally hard-line unionist area of South Belfast and has been the scene of highly publicised anti-Catholic chanting by a section of fans.

In response to the question 'Suppose you were given tickets for a GAA match in Casement Park in Belfast, would you try to go?', twice as many Catholics (77.6\%) as Protestants (38.8\%) said they would go, as shown in Table 3. By contrast, asked the same question in relation to Ravenhill, home of Ulster rugby, $69.3 \%$ of Catholics said they would go compared to $66.3 \%$ of Protestants. Regarding willingness to attend Windsor Park, the national soccer stadium, $56.4 \%$ of Catholics said they would go compared to $60.2 \%$ of Protestants.

Despite the explanatory limitations of these figures, the trends are nonetheless noteworthy. The sharp religious difference in willingness to attend Casement Park is expected, given the divided geography of Belfast, and poses a challenge to the GAA. Rugby has always been the least divisive of the three sports and the stadium is in an area with a relatively untroubled history, but the slightly higher proportion of Catholics 
Table 3. 'Suppose you were given tickets for a match at these venues, would you try to go?'.

\begin{tabular}{lllllll}
\hline & $\begin{array}{l}\text { Casement } \\
\text { Park—GAA }\end{array}$ & & \multicolumn{2}{l}{$\begin{array}{l}\text { Ravenhill-Ulster } \\
\text { Rugby }\end{array}$} & \multicolumn{2}{l}{$\begin{array}{l}\text { Windsor Park-NI } \\
\text { international soccer }\end{array}$} \\
& Yes (\%) & No (\%) & Yes (\%) & No (\%) & Yes (\%) & No (\%) \\
\hline Catholics & 77.6 & 22.4 & 69.3 & 30.7 & 56.4 & 43.6 \\
Protestants & 38.8 & 61.2 & 66.3 & 33.7 & 60.2 & 39.8 \\
No religion & 56.9 & 43.1 & 73.7 & 26.3 & 61.5 & 38.5 \\
All & 58.2 & 41.8 & 68.9 & 31.1 & 58.9 & 41.1 \\
\hline
\end{tabular}

Source: ARK (20I4).

GAA: Gaelic Athletic Association.

willing to attend is still eye-catching, given the traditional Protestant associations of the sport. Regarding the soccer ground, the fact that only slightly fewer Catholics would be willing to attend is also striking. It reinforces the impression noted above that the IFA's attempts to make Northern Ireland international soccer matches more inclusive have met with some success.

Undercutting the impact of territorial division on sport was one of the rationales of the plan to build a new stadium shared by all three sports on the site of the now-defunct Maze prison which held paramilitary prisoners during the Troubles. The potential symbolism of the shared location, built in space previously associated with violence and division, was obvious and would have likely made the other venues of sports more welcoming to people from all backgrounds. However, the plan collapsed in 2009; significantly, the three sports were in support, but the scheme was abandoned due to lack of political consensus on the proposal to build a 'conflict transformation centre' also on the site which unionists worried would become a 'shrine to republican terrorism'. Thus, as Hassan and O'Kane (2012: 399) observe, 'a stadium that had the potential to encapsulate a new beginning to life in Northern Ireland was sacrificed due to a failure to properly draw a line under its disputed past'.

\section{Discussion and conclusion}

The peace process has facilitated a number of significant evolutions in Northern Ireland sport and these developments have fed back into the process of social and political change through their fulfilment, to a degree, of the three peacebuilding functions of sport outlined above: in-group socialisation; building social cohesion across inter-group divides; and the symbolic, sportive expression of new, shared identities. Taking in-group socialisation first, it was noted that it can take two forms: building a democratic culture of peace and strengthening group identity and confidence. The former could be said to have been advanced through the positive and courageous steps taken by the three main sports away from their exclusive sporting and organisational identities and towards fostering a more democratic ethos of tolerance and diversity among their support bases. Rule changes and outreach in the GAA and soccer's Football for All campaign exemplify this progress. In this way, the sports were acting as what Brewer (2010: 55) calls civil society 'institutional spaces' of peacebuilding, showing leadership through modelling, to political leaders and the grassroots, the peace process values of accommodation and togetherness. These developments have fashioned more open personas for the sports 
and contributed to their ability to engage non-traditional constituencies, and the willingness of 'others' to engage with them.

The second peacebuilding function of sport, social cohesion, has been active through initiatives which have used sport as an explicit vehicle for community-relations education and cross-community contact among young people with the aim of building a shared and cohesive society, reversing the segregation and mutual suspicion which sharpened during the years of violence. This effort includes youth programmes run in concert by the three main sports such as the 'Game of Three Halves' and the high level co-operation of the three sports in mutually advantageous initiatives such as 'Sport in the Community' through which they have shared practical knowledge and expertise. As for the third peacebuilding capacity of sport, symbolically expressing new identities, sport has provided a platform for shows of respect between the leaders of unionism and nationalism, albeit momentary and somewhat equivocal, with politicians showing displeasure at the respective national anthems. Here, what was arguably the most potent moment took place outside of Northern Ireland: the visit of Queen Elizabeth to the GAA's Croke Park.

However, the limitations on the operation of the three peacebuilding functions are manifest. Despite moves towards inclusivity and openness, sports continue to fulfil a more insular version of in-group socialisation. The society-wide sectarian system in which community, locality, church, school and sport are linked sustains the de facto single-identity nature of much sport indicated by our findings. This system undermines the ability of inclusivity policies or outreach to upset the demographic make-up of sports, and sports continue to facilitate the separate socialisation of Catholics and Protestants, and fail to advance, in a substantial way, cross-community social cohesion. Moreover, aspects of sports which remain unchanged, such as anthems, symbols and ethos, continue to speak to traditional and exclusive identities. The finding that $57 \%$ of people believe that 'there is nothing wrong with different sports or teams being for Protestants or Catholics' recalls Sugden and Bairner's (1993: 136) comment, over 20 years old, that many sports participants simply do not want sports cultures to change: 'Generally, cultural division is way of life in Northern Ireland to such a degree that most of the population derive comfort from the totems of the separate civil societies'.

Furthermore, the potential for sport to serve a symbolic reconciliatory function through representing the new post-Agreement realities has been drastically inhibited by the nature of the Agreement and the structure of the conflict. South Africa provides an instructive comparison, where such a function was possible because national sports teams could represent a deeply divided society in a state whose borders were uncontested. This is not the case in Northern Ireland where the state, and symbolic representations of the state, remains controversial; this contingency notably hamstrings the most promising focus of shared fandom, the 'national' Northern Ireland soccer team (Bairner, 2013). Moreover, the opportunity for perhaps the most profound symbolic representation of change- $\mathrm{a}$ shared sports stadium - was lost due to political dissensus on outstanding 'conflict legacy' matters.

In sum, while the Northern Ireland case bears out the peacebuilding functions of sport, it also reveals two powerful contextual constraints. First, the building of cross-community social cohesion through sport is circumscribed by the fact that the largest sports are themselves part of a divided civil society which reproduces division and are embedded in group cultures shaped by the conflict; the contradictory 'bonding' and 'bridging' impacts of the sports occur simultaneously. The cross-community work of the main sports could be regarded as mere tinkering at the edges of large and resilient single-identity sporting 
blocs. It is this persistent contradiction which prompts Mac Ginty (2011) to characterise Northern Ireland civil society as a 'hybrid civil society'. Demonstrating how liberal peace assumptions have been distorted by local realities and requirements around the world, Mac Ginty's portrayal of post-1998 civil society in Northern Ireland highlights how liberal peace actors (the British and Irish Governments, the United States and the EU) have co-operated with, funded and lent credibility to certain divisive and arguably illiberal civil society actors (the GAA, Orange Order, ex-combatants, churches), apparently to enhance community-building capacity and encourage moderation, but with limited success in spurring bridge-building across the sectarian divide.

Second, all three peacebuilding functions are constrained by the nature of the political context. Unresolved facets of the conflict - residential segregation, territorial division, educational separation, appropriate transitional justice mechanisms and cultural contestation - continue to limit the extent to which sports can reach outside their traditional domains. Given that it is in the mutual, electoral self-interest of the powersharing parties to maintain distinct identity blocs, incentives to resolve outstanding conflict issues are limited. Indeed, separate sports for separate peoples are not necessarily problematic to a peace process informed by consociationalism which affords some degree of autonomy for identity groups (Lijphart, 1977). Tonge's (2014: 194) assessment of consociational prescriptions for ethnic conflict resonates with the Northern Irish case:

a belief in an organic approach to reintegration is justified in the years following conflict, but when unaccompanied by a longer-term plan for societal integration, does not offer the promise of movement towards reconciliation, instead leading to the restatement of difference.

This study suggests two valuable avenues for further research. First, the Northern Ireland case demonstrates the pertinence of further and comparative research on how features of comparable divided contexts - from 'successful' transitions like South Africa and Bosnia and Herzegovina to stalled or failed peace processes such as Israel-Palestine, Sri Lanka and Lebanon-release, or close down, the peacebuilding capacities of sporting organisations. As noted at the outset, this is a blind spot in the sport and peacebuilding literature, and as Paffenholz (2014) observes, context is key to the capacity of civil society to contribute to peacebuilding.

Second, Northern Ireland contains a cluster of sports-based inclusivity measures which may well be applicable to other contexts. The proliferation of peace processes in the postCold War era led to an accumulation of international knowledge on political interventions and societal healing processes, with the transfer of inspiration and practical tools between contexts (Darby, 2008; Tonge, 2014: 13-15). Similarly, further research on how Northern Ireland's experience in the sporting world can contribute positively in other conflict arenas is worthwhile. The Football for All campaign has received international attention, and indeed, this study adds support to its effectiveness. The (admittedly failed) plan to create a shared sports stadium raises the questions of how shared sporting space may contribute to post-conflict peacebuilding elsewhere. One of the most striking recent developments has been the co-operation, on peacebuilding and practical matters, of the three governing bodies - a counterpoint to the often fractious interactions of the power-sharing political parties. The means and methods by which this co-operation was achieved and is sustained deserve further academic scrutiny in order to ascertain the extent to which it could provide a model for sporting organisations in other divided societies. 


\section{Acknowledgements}

The authors wish to thank the anonymous reviewers for their comments and suggestions.

\section{Funding}

The research detailed here was conducted as part a project entitled Social Exclusion and Sport in Northern Ireland funded by the Office of the First Minister and Deputy First Minister, Equality Directorate Research Branch.

\section{Note}

1. See Technical Notes on Northern Ireland Life and Times Survey (NILT) website. Full details on the methodology of the survey are available at http://www.ark.ac.uk/nilt/2013/tech13.pdf. Results of all survey modules, including an SPSS file of the data, are available on the NILT website.

\section{References}

Allport G (1954) The Nature of Prejudice. Cambridge: Perseus Books.

ARK (2014) Northern Ireland Life and Times Survey, 2013 [computer file]. ARK www.ark.ac.uk/nilt [distributor], June 2014.

Bairner A (1999) Soccer, masculinity and violence in Northern Ireland: Between hooliganism and terrorism. Men and Masculinities 1(3): 284-301.

Bairner A (2013) Sport, the Northern Ireland peace process, and the politics of identity. Journal of Aggression, Conflict and Peace Research 5(4): 220-229.

Belfast Telegraph (2012) GAA and IFA partnership boost. Available at: http://www.belfasttelegraph.co.uk/ sport/gaa/gaa-and-ifa-partnership-boost-16147807.html (accessed 29 January 2013).

Belloni R (2008) Civil society in war-to-democracy transitions. In: Jarstad AK and Sisk TD (eds) From War to Democracy: Dilemmas of Peacebuilding. Cambridge: Cambridge University Press, pp. 182-210.

Brewer J (2010) Peace Processes: A Sociological Approach. Cambridge: Polity.

Brewer J, Higgins G and Teeney F (2011) Religion, Civil Society and Peace in Northern Ireland. Oxford: Oxford University Press.

British Broadcasting Corporation (2011) Caral Ni Chuilin attends NI match at Windsor Park. BBC News Website. Available at: http://www.bbc.co.uk/news/uk-northern-ireland-14466874 (accessed 15 February 2013).

Byrne J, Gormley-Heenan C and Robinson G (2012) Attitudes to peace walls: Research report to Office of the First Minister and Deputy First Minister. ARK Website. Available at: http://www.ark.ac.uk/peacewalls2012/peacewalls2012.pdf (accessed 16 January 2016).

Byrne S (2001) Consociational and civic society approaches to peacebuilding in Northern Ireland. Journal of Peace Research 38(3): 327-352.

Cárdenas A (2012) Exploring the use of sports for peacebuilding and conflict resolution. Working paper series no. 1. Archbishop Desmond Tutu Centre for War and Peace Studies, Liverpool Hope University. Available at: http://tutu.hope.ac.uk/media/liverpoolhope/contentassets/documents/desmondtutucentre/ media,10802,en.pdf (accessed 20 February 2014).

Chambers S and Kopstein J (2001) Bad civil society. Political Theory 29(6): 837-865.

Clerkin M (2015) Ireland's Call: Standing tall for twenty years. Irish Times, 31 January. Available at: http://www.irishtimes.com/sport/rugby/ireland-s-call-standing-tall-for-20-years-1.2085759 (accessed 31 January 2015).

Cochrane F (2013) Northern Ireland: The Reluctant Peace. New Haven, CT: Yale University Press.

Cronin M (2001) Catholics and sport in Northern Ireland: Exclusiveness or inclusiveness? International Sports Studies 20(1): 25-41.

Darby J (2008) Borrowing and lending in peace processes. In: Darby J and Mac Ginty R (eds) Contemporary Peacemaking. Basingstoke: Palgrave Macmillan, pp. 339-351.

Darby J and Mac Ginty R (2000) Conclusion: The management of peace. In: Darby J and Mac Ginty R (eds) The Management of Peace Processes. Basingstoke: Palgrave Macmillan, pp. 228-261.

Darnell S (2012) Sport for Development and Peace: A Critical Sociology. London: Bloomsbury Academic.

Dorokhina O, Hosta M and van Sterkenburg J (2011) Targeting Social Cohesion in Post-Conflict Societies through Sport. Council of Europe. Available at: http://www.coe.int/t/dg4/epas/Publications/publications collection_handbook_en.asp (accessed 16 February 2013). 
Gasser P and Levinson A (2004) Breaking post-war ice: Open fun football schools in Bosnia and Herzegovina. Sport in Society 7(3): 467-472.

Giulianotti R (2011) Sport, peacemaking and conflict resolution: A contextual analysis and modelling of the sport, development and peace sector. Ethnic and Racial Studies 34: 207-228.

Giulianotti R (2012) The sport for development and peace sector: An analysis of its emergence, key institutions and social possibilities. Brown Journal of World Affairs 18(11): 279-293.

Guelke A (2012) Politics in Deeply Divided Societies. Cambridge: Polity.

Hargie O, Somerville I and Mitchell D (2015) Sport and Social Exclusion in Northern Ireland: A Report of Research Funded by the Office of the First Minister and Deputy First Minister. Belfast: Office of the First Minister and Deputy First Minister.

Hassan D (2002) A people apart: Soccer, identity and Irish nationalists in Northern Ireland. Soccer and Society 3(4): $65-83$.

Hassan D (2005) The GAA, Rule 21 and police reform in Northern Ireland. Journal of Sport \& Social Issues 29(1): 60-78.

Hassan D and O'Kane P (2012) Terrorism and the abnormality of sport in Northern Ireland. International Review for the Sociology of Sport 47(3): 397-413.

Hassan D and Telford R (2014) Sport and community integration in Northern Ireland. Sport in Society 17(1): 89-101.

Higson R (2008) Anti-consociationalism and the Good Friday Agreement: A rejoinder. Journal of Peace, Conflict and Development 12. Available at: http://www.brad.ac.uk/ssis/peace-conflict-and-development/ issue-12/Anti-consociationalism-and-the-Good-Friday-Agreement,-A-Rejoinder.pdf (accessed 20 January 2014).

Höglund K and Sundberg R (2008) Reconciliation through sports? The case of South Africa. Third World Quarterly 29(4): 805-818.

Keim M (2003) Nation-Building at Play-Sport as a Tool for Social Integration in Post-Apartheid South Africa. Aachen: Meyer \& Meyer.

Kidd B (2008) A new social movement: Sport for development and peace. Sport in Society 11(4): 370-380.

Lederach JP (1997) Building Peace: Sustainable Reconciliation in Divided Societies. Washington, DC: United States Institute of Peace.

Liechty J and Clegg C (2001) Moving beyond Sectarianism: Religion, Conflict and Reconciliation in Northern Ireland. Dublin: Columba Press.

Lijphart A (1977) Democracy in Plural Societies: A Comparative Exploration. New Haven, CT: Yale University Press.

Mac Ginty R (2011) International Peacebuilding and Local Resistance: Hybrid Forms of Peace. Basingstoke: Palgrave Macmillan.

McCall C (2006) From 'long war' to 'war of the lilies': 'Post-Conflict' territorial compromise and the return of cultural politics. In: Cox M, Guelke A and Stephen F (eds) A Farewell to Arms?: Beyond the Good Friday Agreement, 2nd edn. Manchester: Manchester University Press, pp. 302-316.

McClancy J (1996) Sport, Identity and Ethnicity. Oxford: Berg Publishers.

McGarry J and O'Leary B (1993) The Politics of Antagonism: Understanding Northern Ireland. London: Athlone Press.

McGarry J and O’Leary B (2009) Power shared after the deaths of thousands. In: Taylor R (ed.) Consociational Theory: McGarry and O'Leary and the Northern Ireland Conflict. Abingdon: Routledge, pp. 15-84.

Mallon S (2013) Attendance at Live Sports Events by Adults in Northern Ireland. Department of Culture, Arts and Leisure. Available at: https:/www.communities-ni.gov.uk/sites/default/files/publications/ dcal/attendance-at-live-sports-events-by-adults-in-northern-ireland-201112_0.pdf (accessed 31 January 2015).

Merkel U (2008) The politics of sport diplomacy and reunification in divided Korea: One nation, two countries and three flags. International Review for the Sociology of Sport 43(3): 289-311.

Mitchell D (2015) Politics and Peace in Northern Ireland: Political Parties and the Implementation of the 1998 Agreement. Manchester: Manchester University Press.

Nolan P (2014) Northern Ireland Peace Monitoring Report: Number Three. Community Relations Council. Available at: http://www.community-relations.org.uk/wp-content/uploads/2013/11/Peace-MonitoringReport-2014.pdf (accessed 5 January 2016).

Nolan P, Bryan D, Dwyer C, et al. (2014) The Flag Dispute: Anatomy of a Protest. Belfast: Queen's University. Office of the First Minister and Deputy First Minister (2013) Together: Building a United Community. Available at: https://www.executiveoffice-ni.gov.uk/sites/default/files/publications/ofmdfm_dev/together-buildinga-united-community-strategy.pdf (accessed 20 June 2016). 
Paffenholz T (ed.) (2010) Civil Society and Peacebuilding: A Critical Assessment. Boulder, CO: Lynne Rienner.

Paffenholz T (2014) International peacebuilding goes local: Analysing Lederach's conflict transformation theory and its ambivalent encounter with 20 years of practice. Peacebuilding 2(1): 11-27.

Paffenholz T and Spurk C (2010) A comprehensive analytical framework. In: Paffenholz T (ed.) Civil Society and Peacebuilding: A Critical Assessment. Boulder, CO: Lynne Rienner, pp. 65-78.

Paris R (2004) At War's End: Building Peace after Civil Conflict. Cambridge: Cambridge University Press.

Parry J (2012) The power of sport in peacemaking and peacekeeping. Sport in Society 15(6): 775-787.

Putnam R (2000) Bowling Alone: The Collapse and Revival of American Community. New York: Simon and Schuster.

Reiche D (2011) War minus the shooting? The politics of sport in Lebanon as a unique case in comparative politics. Third World Quarterly 32(2): 261-277.

Ruane J and Todd J (1996) The Dynamics of Conflict in Northern Ireland: Power, Conflict, and Emancipation. Cambridge: Cambridge University Press.

Spurk C (2010) Understanding civil society. In: Paffenholz T (ed.) Civil Society and Peacebuilding: A Critical Assessment. Boulder, CO: Lynne Rienner, pp. 2-28.

Sugden J (2010) Critical left-realism and sport interventions in divided societies. International Review for the Sociology of Sport 45(3): 258-272.

Sugden J and Bairner A (1993) Sport and Sectarianism in a Divided Ireland. Leicester: Leicester University Press.

Sugden J and Bairner A (eds) (2000) Sport in Divided Societies. Aachen: Meyer \& Meyer.

Taylor R (2009) The injustice of a consociational solution to the Northern Ireland problem. In: Taylor R (ed.) Consociational Theory: McGarry and O'Leary and the Northern Ireland Conflict. Abingdon: Routledge, pp. 309-330.

Tonge J (2014) Comparative Peace Processes. Cambridge: Polity.

Tuohey B and Cognato B (2011) Peace players international: A case study on the use of sport as a tool for conflict transformation. SAIS Review 31(1): 51-63.

Varshney A (2001) Ethnic conflict and civil society: India and beyond. World Politics 53(3): 362-398.

Wilson R (2005) Football for all: A baseline study. CAIN Web Service. Available at: http://cain.ulst.ac.uk/ issues/sport/docs/wilson1205.pdf (accessed 27 January 2013).

Wilson R (2010) The Northern Ireland Experience of Conflict and Agreement: A Model for Export? Manchester: Manchester University Press.

Wilson R (2011) Evaluating Football for All. Belfast: Irish Football Association.

Wood S (2013) Football after Yugoslavia: Conflict, reconciliation and the regional football league debate. Sport in Society 16(8): 1077-1090. 